\title{
Importance of Grassland in New Zealand
}

L ORD BLEDISLOE'S tenure of office as suredly had a significance that will come to be regarded as of great historical interest. Because he is himself an expert agriculturist, and a pioneer in the movement which led to the establishment of a co-ordinated system of agricultural research in Great Britain and throughout the Empire, he has been able to take an informed and truly helpful interest in the Dominion's leading industry-agriculture.

From time to time, Lord Bledisloe has delivered a number of addresses-addresses of a practical and technical nature-to the farmers of the Dominion. In all these addresses, the great importance of research has been emphasised and the results of investigations conducted in Great Britain and in all parts of the world brought to the notice of his audiences.

In his most recent address, when opening the Third Conference of the New Zealand Grassland Association at Palmerston North, on October 2, Lord Bledisloe most appropriately has taken grassland as his subject*. New Zealand stands in a unique position relative to her sources of wealth. They are based to an overwhelming extent on her grasslands and on her exports to Great Britain. Grassland products form 94 per cent of her total exports-while 70 per cent of her exports cannot at present be marketed elsewhere than in Great Britain.

In the changing world of to-day, these two facts present very difficult problems for solution at the hands of both the Dominion herself and of Great Britain. New Zealand could easily increase vastly the amount of her grassland products-Lord Bledisloe has no difficulty in making this abundantly clearbut relatively speaking, Great Britain could undoubtedly do the same to an even greater extent. This is epitomatic of the economic tangle in which the whole world is engulfed. Lord Bledisloe in his address is, however, concerned not with world problems, not with the grasslands of the world, but explicitly with the grasslands of New Zealand. $\mathrm{He}$ perhaps places the advantages which New Zealand possesses in the matter of a perfect balance between sun and shower rather too high, when he gives it as

* Grassland : the Main Source of the Nation's True Wealth. By Lord Bledisloe. Pp. 36. (Auckland, N.Z.: Gordon and Gotch (A'sia), his opinion that the potential output of meat and milk from the sown pastures of New Zealand would be at an average per acre of 60 per cent above that of Great Britain -always above, emphatically, but not 60 per cent above what the sown pastures of Britain could be made to be.

With great justice, Lord Bledisloe urges the New Zealand farmers to give more attention to the production of supplementary crops-silage and fodder crops for winter feed. He also considers that the Dominion would be well advised to extend the scope of her products for export ; and remarks ". . . there is in this Dominion an urgent need for more diversified farming based upon the current requirements, within saturation limits, of overseas markets". He points to the part which the pig may be made to play in connexion with the small dairy farm; and it is certainly remarkable that the New Zealand dairy industry has been built up without any supplementary aid from concomitant swine husbandry.

Lord Bledisloe considers that the dairy farmers should pay a great deal more attention to cheese, and especially to the quality of the cheese produced. In this connexion, he emphasises the important fact that what is a good pasture for other livestock products is not necessarily a good pasture for cheese production, and incidentally directs attention to a matter, the ad hoc uses to which pastures are put, which has nowhere been made the subject of sufficiently critical investigation.

Lord Bledisloe concludes his address with an admirable summary of recent grassland research, and emphasises the strides New Zealand is making by means of schemes of certification applied to her grassland seeds. There is not the least doubt that certified New Zealand white clover and Akaroa cocksfoot have a very considerable usefulness in Great Britain. It must not, however, be thought that the Hawke's Bay rye-grass for our purposes can be placed in the same category as seed taken from genuine old Kentish pastures, even if 'somewhat inferior' to our authen. ticated strains. The Hawke's Bay rye-grass in Britain behaves more like 'commercial' than like 'indigenous' strains. It is, however, more permanent than the commercial and therefore, as Lord Bledisloe remarks, superior to it for long leys--but for such long leys (as equally for permanent pasture) the genuine Kentish rye-grass is in a class to itself.

\section{Early Science in Oxford}

$\mathrm{T}$ HE appointment of a reader in the history of science at Oxford is a notable event, and the inaugural lecture of Dr. R. 'T. Gunther, the first holder of the post, contains much interesting information not generally known*. It deserves careful study, and may, it is to be hoped, arouse the interest of the University of Oxford to a consciousness of what has already been done by Oxford towards the promotion of science, and what it might do in the special but philosophical field of the history of science.

Roger Bacon studied in Oxford; the earlier meetings of the Royal Society took place in Oxford, in Wad-

* Oxford and the History of Science : with an Appendix on Scientifle Collections in College Libraries. Dr. R. T. Gunther. Pp. 49. (London: Oxford University Press, 1934.) 28. net. ham College in the time of Wallis; Christopher Wren. was a Wadham man and Savilian professor of astronomy; Rigaud, another Savilian professor, was one of the first historians of science, and Oxford has now appointed the first reader in the subject. Dr. Gunther is a Magdalen man, and he tells in his lecture a good deal about the work and collections of Dr. Daubeny, another Magdalen man, made a fellow of the Royal Society in 1822. Considering what Dr. Gunther has done, in pious memory and scientific sequence to Dr. Daubeny, considering too that Dr. Charles Singer, a leading historian of science, is also from Magdalen, that famous and opulent foundation may fairly take its place by the side of Wadham on the rôle of Oxford science. 